\title{
Haemoglobin Bart's hydrops syndrome in Greece
}

\author{
C KATTAMIS, A METAXOTOU-MAVROMATI, E TSIARTA, C METAXATOU, P WASI, \\ W G WOOD, L PRESSLEY, D R HIGGS, J B CLEGG, D J WEATHERALL
}

\section{Summary and conclusions}

A case of haemoglobin Bart's hydrops syndrome was characterised in a Greek family with a history of three other fetuses with hydrops. Family studies showed that both the mother and father carried $\alpha$-thalassaemia genes, and globin-chain synthesis analysis of the present fetus showed a total absence of $\alpha$-chain production. The haemoglobin composition of the fetus was similar to that seen in cases in south-east Asia, and analysis of DNA from the Greek case confirmed the total deletion of the $\alpha$-chain genes. The extent of the deletion, however, differed from that seen in south-east Asian cases and included the loss of one of the embryonic $\zeta$-chain genes.

Thus the severe form of $\alpha$-thalassaemia occurs in Greece but has arisen independently from the similar condition in south-east Asia. The condition must be considered in any woman of this racial background who gives a history of unexplained stillbirths.

\section{Introduction}

The haemoglobin Bart's hydrops syndrome is a relatively common cause of fetal loss in south-east Asia. ${ }^{1}$ It results from the homozygous state for an $\alpha$-thalassaemia determinant in which there is deletion of both $\alpha$-globin chain genes, which are normally closely linked on chromosome $16 .^{2-4}$ Affected fetuses produce no $\alpha$-chains and thus make no $\operatorname{HbF}\left(\alpha_{2} \gamma_{2}\right)$; the resulting excess $\gamma$-chains form Hb Bart's $\left(\gamma_{4}\right)$, which is ineffective as an oxygen carrier. Hence they die from severe hypoxia and anaemia, either in utero or immediately after delivery.

Despite the high prevalence of $\alpha$-thalassaemia in Mediterranean races there have been few reports of the Hb Bart's hydrops fetalis syndrome in these populations. ${ }^{5-7}$ This may be because either the condition has not been recognised by clinicians or the $\alpha$-thalassaemia determinant that causes it is uncommon in these populations.

We describe a Greek family in which a woman with a history of repeated fetal loss produced a stillborn fetus with the $\mathrm{Hb}$ Bart's hydrops syndrome; analysis of the globin genes disclosed a hitherto undescribed type of $\alpha$-globin gene deletion that differs from that causing the disorder in Oriental populations.

\section{Materials and methods}

Fetal blood was obtained from the umbilical cord at delivery, and a further sample was obtained by cardiac puncture 12 hours later, when the spleen and liver were removed and stored at $-70^{\circ} \mathrm{C}$ until DNA was extracted. Blood films were made from the initial sample and the remainder used for haemoglobin analysis ${ }^{8}$ and globin-chain synthesis studies. ${ }^{9}$

DNA was extracted from the spleen of the fetus and from the white blood cells of the parents. The samples were digested with various restriction enzymes and analysed by electrophoresis on agarose gels. After transfer to nitrocellulose filters, globin gene fragments were localised by hybridisation with ${ }^{32} \mathrm{p}$-labelled $\alpha$-globin and $\zeta$-globin gene probes followed by autoradiography as described. ${ }^{10}$

\section{Results}

CLINICAL FINDINGS

The family originated from Lesbos. Three pregnancies had ended at 28-30 weeks' gestation with the delivery of stillborn fetuses with hydrops. Examination of the third fetus showed gross hepatosplenomegaly and marked extramedullary erythropoiesis. A fourth pregnancy was uneventful until 28 weeks' gestation, when the mother developed eclampsia; two days later a stillborn fetus with hydrops was delivered. The placenta weighed $1400 \mathrm{~g}$ and the fetus measured $35 \mathrm{~cm}$ and weighed $1850 \mathrm{~g}$. The liver $(125 \mathrm{~g})$ and spleen $(12 \mathrm{~g})$ were about four times the normal size and showed increased erythropoiesis; there was a moderate amount of haemosiderosis in the liver and an absence of white pulp in the spleen. Erythropoietic foci were also observed in the kidneys and adrenal glands, which were oedematous.

Studies of the parents showed that both were blood group $\mathrm{O}$, Rh-positive, and had normal chromosome karyotypes. Results of serological screening of the mother for syphilis, toxoplasmosis, and Mycoplasma pneumoniae were negative.

\section{HAEMATOLOGICAL AND HAEMOGLOBIN ANALYSIS OF FETUS}

The peripheral blood film (fig 1) showed severe abnormalities of the red cells including anisopoikilocytosis, extreme hypochromia, and numerous nucleated red cells at all stages of maturity. The haemoglobin consisted mainly of $\mathrm{Hb}$ Bart's $\left(\gamma_{4}\right)$ with small amounts of $\mathrm{HbH}\left(\beta_{4}\right)$ and the embryonic haemoglobin $\mathrm{Hb}$ Portland $\left(\zeta_{2} \gamma_{2}\right)$;

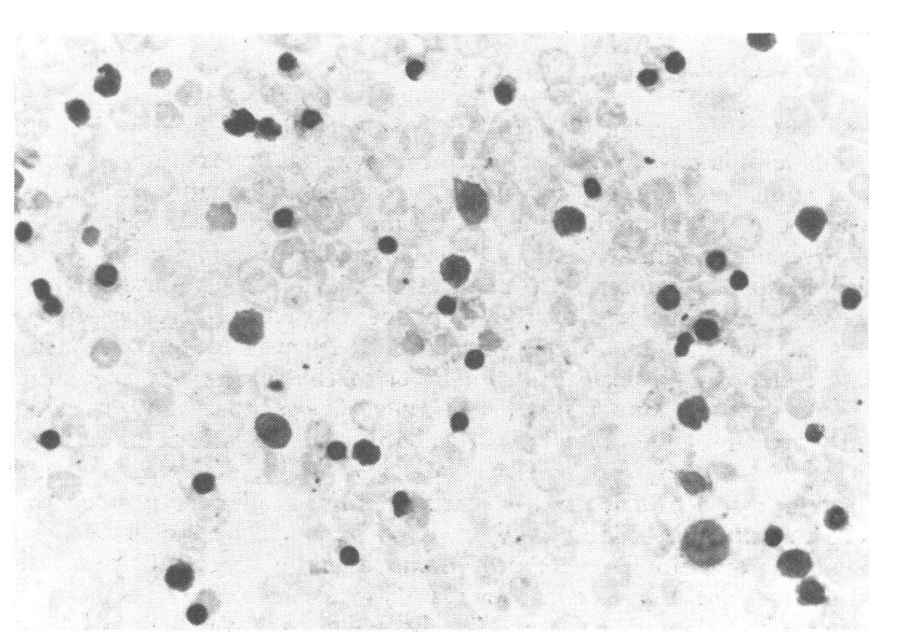

FIG I-Peripheral blood film of fetus with hydrops. (Original magnification $\times 750$.)

\footnotetext{
Thalassaemia Unit, 1st Department of Paediatrics, Athens University, Aghia Sophia Children's Hospital, Athens, Greece

C KATTAMIS, MD, professor of paediatrics

A METAXOTOU-MAVROMATI, MD, registrar in paediatrics

E TSIARTA, MD, biochemist

C METAXATOU, MD, senior lecturer in paediatrics

Department of Medicine, Siriraj Hospital, Bangkok, Thailand P WASI, MD, professor

MRC Molecular Haematology Unit, Nuffield Department of Clinica Medicine, John Radcliffe Hospital, Oxford 0X3 9DU

W G WOOD, PHD, external staff member

L PRESSLEY, $M B$, research fellow

RIGGS, MB, MRCP, research fellow

D J WEATHERALL, MD, FRCP, FRS, Nuffield professor
}




no $\mathrm{HbA}$ or $\mathrm{HbF}$ was detected (fig 2). There were trace amounts of a fourth haemoglobin component migrating between the positions of $\mathrm{HbF}$ and $\mathrm{HbA}_{2}$ and similar in mobility to the $\mathrm{Hb}-\mathrm{X}$ component described in young fetuses ${ }^{11}$ and in the leukaemia cell line K562. ${ }^{12}$

Analysis of globin-chain synthesis showed that only $\gamma$-chains and $\beta$-chains were being produced in the reticulocytes of the fetus; there was no $\alpha$-chain synthesis (fig 3 ); the $\zeta$-chains of $\mathrm{Hb}$ Portland

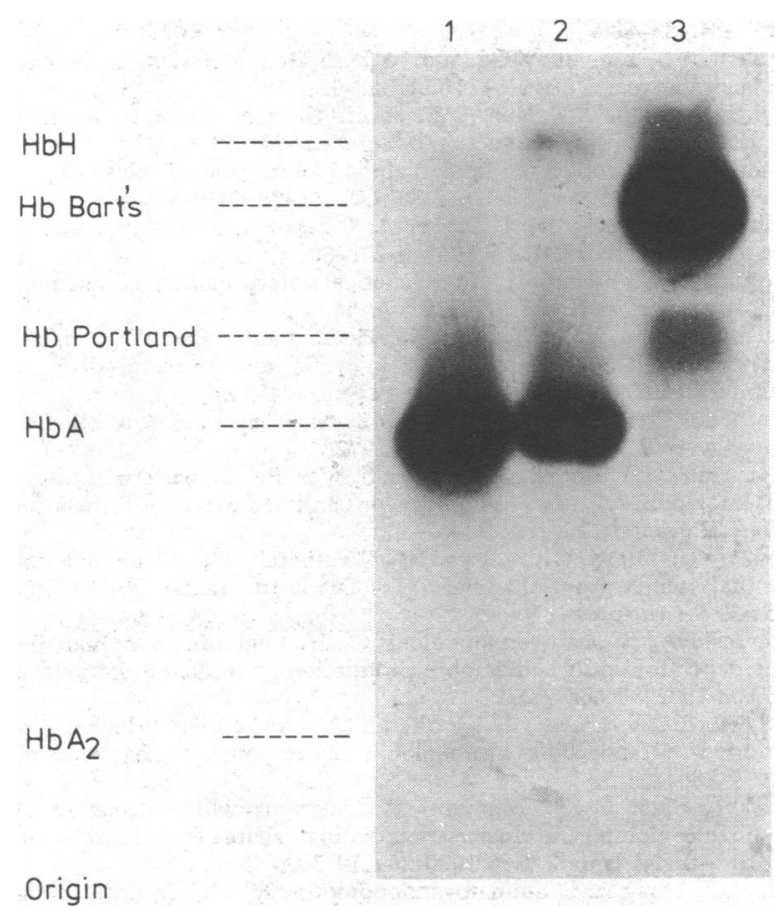

FIG 2-Starch-gel electrophoresis of haemolysates from normal adult (1) subject with $\mathrm{HbH}$ disease (2) and Greek fetus with hydrops (3).

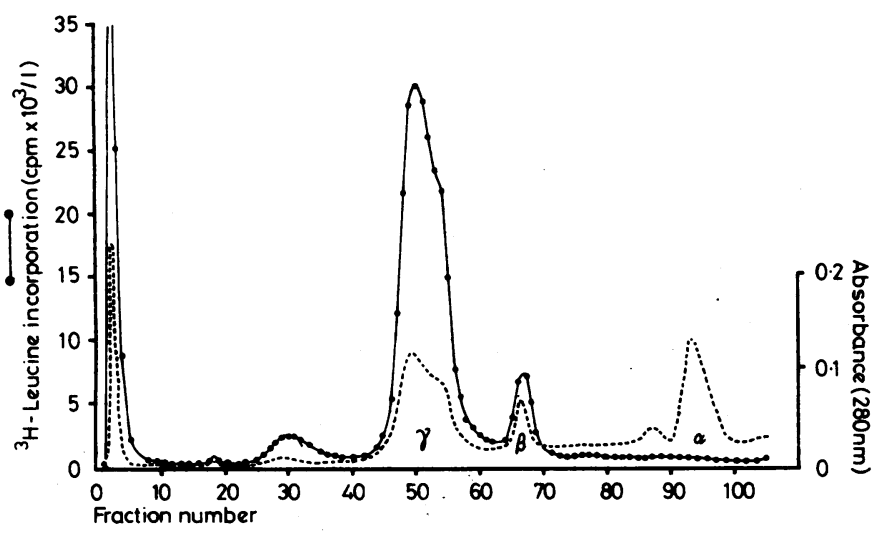

FIG 3-Analysis of globin-chain synthesis ( $\gamma$-chains and $\beta$-chains) in fetus with hydrops. Normal cord-blood globin added to provide marker for elution position of $\alpha$-chains. are not detectable in this analysis. Structural analysis of the $\mathrm{Hb}$ Portland fraction confirmed the presence of $\zeta$-chain peptides.

\section{FAMILY STUDY}

The table gives haematological data on the parents. The red cells of the father showed minor morphological abnormalities and occasional inclusion bodies on incubation with brilliant cresyl blue. Haemoglobin analysis showed a $\mathrm{HbA}_{2}$ content of $6.5 \%$, indicating that he was a $\beta$-thalassaemia carrier. Analysis of globin-chain synthesis, however, failed to show a deficit of $\beta$-chain production, suggesting compound heterozygosity for both $\alpha$-thalassaemia and $\beta$-thalassaemia.

The mother's red cells showed typical thalassaemic changes, with occasoinal cells containing $\mathrm{HbH}$ inclusions; the $\alpha: \beta$-globin chain synthesis ratio was 0.7 ; which is in keeping with a diagnosis of the severe form of $\alpha$-thalassaemia trait ( $\alpha$ thal 1$).^{8}$

\section{GLOBIN GENE ANALYSIS}

Full details of globin gene analysis of this family are presented elsewhere. ${ }^{10}$ DNA from the fetus with hydrops, digested with a series of restriction endonucleases and hybridised with an $\alpha$-genespecific probe, showed no $\alpha$-gene-specific bands, indicating total deletion of the $\alpha$-chain genes. The two $\alpha$-chain genes on chromosome 16 are linked to the embryonic $\alpha$-like globin genes, the $\zeta$-genes, and are separated from them by an $\alpha$-like pseudogene $\psi \alpha$; the chromosomal arrangement of these genes is $5^{\prime}-\zeta 2-\zeta 1-\psi \alpha-\alpha 2-\alpha 1-3^{\prime}{ }^{13}$ To determine the extent of the deletion the DNA was examined further using a $\zeta$-gene-specific probe. Only the $\zeta 2$-gene fragment could be detected, suggesting that the disorder had resulted from an extensive gene deletion of both $\alpha$-genes and the $\psi \alpha-$ gene and $\zeta 1$-gene. Its minimum size has been calculated as $\mathbf{1 7 . 4}$ kilobases. In contrast DNA from a fetus with $\mathrm{Hb}$ Bart's hydrops from Thailand had retained both $\zeta$-genes but lost the $\psi \alpha$-gene and both $\alpha$-genes. ${ }^{10}$

Restriction-enzyme analysis of the parents of the Greek fetus with hydrops was entirely consistent with their each having lost both $\alpha$-chain genes from chromosome 16 .

\section{Discussion}

Our study provides the first complete analysis of the Hb Bart's hydrops syndrome in a family of non-Oriental origin. Our haematological findings and the haemoglobin constitution of the fetus were closely similar to those reported for the Hb Bart's hydrops fetalis syndrome in south-east Asia. ${ }^{1}$ Reports of this condition in Mediterranean populations have been restricted to an incompletely characterised case diagnosed retrospectively from family studies, a case report showing similar clinical and haematological findings to the present case, ${ }^{5}$ and a recent report describing an infant with hydrops in which $\alpha$-chains were produced, albeit at a reduced amount. ${ }^{7}$ The third case clearly cannot be the result of total $\alpha$-gene deletion.

Because of the relatively high prevalence of $\alpha$-thalassaemia in Greece and throughout the Mediterranean, ${ }^{8}$ the rarity of reported cases of Hb Bart's hydrops fetalis suggests that either

Haematological data and results of globin-chain synthesis studies

\begin{tabular}{|c|c|c|c|c|c|c|c|c|c|c|c|c|c|c|c|}
\hline \multirow{2}{*}{\multicolumn{3}{|c|}{ Subject }} & \multirow[b]{2}{*}{$\underset{(\mathbf{g} / \mathbf{d l})}{\mathbf{H b}}$} & \multirow[b]{2}{*}{$\begin{array}{c}\text { Packed } \\
\text { cell } \\
\text { volume* }\end{array}$} & \multicolumn{3}{|c|}{ Red cell morphology } & \multirow[b]{2}{*}{$\begin{array}{l}\text { Osmotic } \\
\text { fragility }\end{array}$} & \multirow[b]{2}{*}{$\begin{array}{c}\text { Inclusion } \\
\text { bodies }\end{array}$} & \multicolumn{2}{|c|}{ Blood groups } & \multirow[b]{2}{*}{$\underset{(\%)}{\text { HbA }_{2}}$} & \multirow[b]{2}{*}{$\underset{(\%)}{\text { HbF }}$} & \multicolumn{2}{|c|}{$\alpha \mathbf{H b}: \beta \mathbf{H b}$ ratio } \\
\hline & & & & & $\begin{array}{l}\text { Micro-- } \\
\text { cytosis }\end{array}$ & $\begin{array}{l}\text { Hypo- } \\
\text { chromia }\end{array}$ & $\begin{array}{l}\text { Poikilo- } \\
\text { cytosis }\end{array}$ & & & ABO & $\mathbf{R h}$ & & & $\begin{array}{l}\text { Total } \\
\text { counts }\end{array}$ & $\begin{array}{c}\text { Specific } \\
\text { activity } \\
\text { (cpm/ODaso) }\end{array}$ \\
\hline Father & .. & .. & T5.9 & 0.49 & + & + & + & +++ & $1 / 2000$ & $\mathbf{O}$ & Positive & 6.5 & $<2$ & $1 \cdot 10$ & 0.93 \\
\hline Mother & .. & .. & $11 \cdot 2$ & $0 \cdot 39$ & + & ++ & + & +++ & $1 / 1000$ & $\mathbf{0}$ & Positive & 2.9 & $<2$ & $\begin{array}{l}0.71 \\
0.65\end{array}$ & 0.55 \\
\hline $\begin{array}{l}\text { Hydropic } \\
\text { blood) }\end{array}$ & fetus & $\begin{array}{c}\text { cord } \\
. .\end{array}$ & $4 \cdot 2$ & 0.27 & ++ & +++ & +++ & +++ & Many & $\mathbf{O}$ & Positive & & & & \\
\hline
\end{tabular}

*Conversion: SI to traditional units $-0.49=49 \%$.
$+=$ Mild. $++=$ Moderate. $+++=$ Severe. 
this condition is not being recognised by obstetricians or the particular $\alpha$-thalassaemia determinant that causes it-namely, one in which both $\alpha$-globin genes are absent or non-functioning on one chromosome-is rare in this area. Forms of $\alpha$-thalassaemia in which both $\alpha$-chain genes on one chromosome have been deleted have been described in Cyprus and Sardinia. ${ }^{14}$ The $\zeta$-genes in these subjects, however, remain to be investigated. This is important since probably Hb Portland $\left(\zeta_{2} \gamma_{2}\right)$ is the only functioning haemoglobin present in fetuses with $\mathrm{Hb}$ Bart's hydrops; Hb Bart's is physiologically non-functional. ${ }^{8}$ A gene deletion that removed both the $\zeta$-chains and the $\alpha$-genes would, in the homozygous state, prevent the synthesis of any $\mathrm{Hb}$ Portland and presumably be incompatible with survival of the embryo. Such a deletion, if common, might explain the high incidence of $\alpha$-thalassaemia and the lack of fetuses with $\mathrm{Hb}$ Bart's hydrops.

Interestingly, the gene deletion in the Greek case of Hb Bart's hydrops in our study is different from that found in a similarly affected fetus from Thailand.10 In the second case both $\zeta$-genes were intact, whereas in the Greek case only one remained. If the number of $\zeta$-chain genes is reflected by the amount of $\mathrm{Hb}$ Portland produced, fetuses homozygous for the more extensive deletion may be more severely affected and stillbirth may occur earlier in pregnancy. In Thailand most fetuses with $\mathrm{Hb}$ Bart's hydrops survive until term ${ }^{8}$; the Greek fetus was delivered at 28 weeks, as were three others in the same family.

A form of $\alpha$-thalassaemia in which intact $\alpha$-chain genes direct the synthesis of a reduced amount, but not a total deficit, of $\alpha$-chains has also been described in Cyprus and Sardinia. ${ }^{14}$ If this type of $\alpha$-thalassaemia proved to be common in other parts of the Mediterranean region it could also explain a low incidence of $\mathrm{Hb}$ Bart's hydrops fetalis.

Despite these arguments, we cannot exclude the possibility that the Hb Bart's hydrops fetalis syndrome occurs more commonly in this region than has been recognised. Indeed, since this work was completed we have seen two similar cases in Cypriots (Sophocleous T, Marsh G, personal communication). This report should alert obstetricians in the Mediterranean area to consider $\alpha$-thalassaemia in cases of fetuses with hydrops in which other causes have been excluded.

This work was supported by the National Research Institute of Greece and the Ministry of Social Services, Greece.

\section{References}

1 Wasi P, Na-Nakorn S, Pootrakul S. The $\alpha$ thalassaemias. Clin Haematol $1974 ; 3: 383-411$.

2 Ottolenghi S, Lanyon WG, Paul J, et al. Gene deletion as the cause of $\alpha$ thalassaemia. Nature $1974 ; 251$ :389-92.

3 Taylor JM, Dozy A, Kan YW, et al. Genetic lesion in homozygous $\alpha$ thalassaemia (hydrops fetalis). Nature $1974 ; 251: 392-3$.

Orkin SH. The duplicated human alpha globin genes lie close together in cellular DNA. Proc Nat Acad Sci USA 1978;5950-4.

5 Diamond MP, Cotgreve I, Parker A. Case of intrauterine death due to $\alpha$-thalassaemia. $\mathrm{Br} \mathrm{Med} \mathcal{F} 1965 ; \mathrm{ii}: 278-80$.

- Kattamis C, Lehmann H. The genetical interpretation of haemoglobin H disease. Hum Hered 1970;20:156-64.

' Sharma RS, Yu V, Walters WAW. Haemoglobin Bart's hydrops fetalis syndrome in an infant of Greek origin and prenatal diagnosis of alpha-thalassaemia. Med $\mathcal{f}$ Austr 1979 ;ii:404-34.

8 Weatherall DJ, Clegg JB. The thalassaemia syndromes. 2nd ed. Oxford: Blackwell Scientific Publications, 1972.

- Weatherall DJ, Clegg JB, Na-Nakorn S, Wasi P. The pattern of disordered haemoglobin synthesis in homozygous and heterozygous $\beta$ thalassaemia. Br F Haematol 1969;16:251-67.

${ }^{10}$ Pressley L, Higgs DR, Clegg JB, Weatherall DJ. Gene deletions in $\alpha$ thalassemia prove that the $5^{\prime} \zeta$-locus is functional. Proc Natl Acad Sci USA (in press).

11 Pataryas HA, Stamatoyannopoulous G. Hemoglobin in human fetuses. Evidence for adult hemoglobin production after 11 th gestational week. Blood 1972;39:688-96.

12 Rutherford TR, Clegg JB, Weatherall DJ. K562 human leukaemic cells synthesise embryonic haemoglobin in response to haemin. Nature 1979;280:164-5.

${ }^{13}$ Lauer J, Shen C-KJ, Maniatis T. Deletions which occur in cloned human $\alpha$-globin gene cluster are indistinguishable from those associated with $\alpha$-thalassemia 2. Cell 1980;20:119-30.

14 Kan YW, Dozy AM, Stamatoyannopoulous G, et al. Molecular basis of hemoglobin-H disease in the Mediterranean population. Blood 1979;54: 1434-8.

(Accepted 3 Fune 1980)
ONE HUNDRED YEARS AGO At the recent trial at the Circuit Court, Dumfries, of James Dunning, a farm-servant, on the charge of murder, it transpired that, on the evening of Saturday, the 3rd of April last, the prisoner and three other men of his class, respectable and industrious agricultural labourers, accompanied by the sister of one of them, who was also a farm-worker, met together in the town of Glenluce, and, having adjourned to a public house, consumed in two hours an amount of whiskey which the lowest estimate placed at three Scotch half-pints (equal to nearly three English quarts), and the highest at four Scotch half-pints (equal to nearly four English quarts). The woman did not partake of the whiskey, but had a glass of wine; so that the four men had amongst them, on the most moderate computation, three quart bottles of whiskey. Not content with this, they purchased, on leaving the inn, another quart bottle of whiskey amongst them, with which to regale themselves on their walk home, if that can be called a walk, which was really a drunken stagger, varied by occasional delirious outbursts. "The four men," said the female participator in this orgie, "were all the worse of drink when we started, and they drank out of the bottle as we went. ... Harvey" (one of the men) "was just jumping along the road, swearing. He fell down at the bogs of Barnsallie. He ran in about the side of the road where there were rashes (rushes) growing. Ramsey and I lifted him up, and we went along together again. He was still swearing. He went before us; and, when we came up, he uttered an oath, and gave Ramsey a shove, causing him to fall on his hands on the bank." "I had just as much drink as I could well walk with," said another of the men named Murray, of whom a witness, at whose house he called, deposed that he was so "fractious and violent with drink that he struck a chair with his fist, and knocked a piece of skin off his knuckles, which bled; that he wanted to strike the mantelpiece, and threatened to whitewash the walls with her daughter's brains if she did not say she was his friend." The third of the men, named Ramsay, was found on the following morning, in the ditch by the roadside, with injuries on his head, from which he soon afterwards died; and the fourth of them was tried on the 31st instant for having caused his death; and, although acquitted of the murder, was proved to have been drunk and incapable in the company of the murdered man. This shocking story must not be taken as illustrative of the manners and customs of the agricultural labourers of the South of Scotland, who are, as a rule, a sober and thrifty class; but many of whom, unfortunately, have a most reprehensible practice of getting deliberately drunk periodically at certain fairs and markets. These occasional isolated acts of drunkenness are looked forward to as pleasant variations in what is a somewhat dreary and monotonous existence, and are not very seriously condemned by the moral sentiment of the district. Wives and mothers make preparations for them; and a decent prudent father of a family will be brought home once or twice a year helplessly or uproariously drunk-more often the latter than the former-without feeling that he has forfeited his good name or influence, or done anything more reprehensible than commit a rather broad practical joke. The generally uproarious character of the occasional drunkenness of the Scotch hind or bondager is, perhaps, to be attributed partly to the effects on the nervous centres of a sudden and unaccustomed inundation of alcohol, at a time when they have been stirred out of their wonted lethargy, and slightly stimulated by social excitement; and partly to the injurious effects of young coarse spirit, containing fusel oil and other deleterious ingredients. Whatever its explanation may be, the fact that Caledonian drunkenness is like its scenery, "stern and wild," is unquestionable. Its violent and tumultuous character leads to brawls on the highways, and not to the comatose slumbers in dark corners of Anglican beerdrinking; and hence, perhaps, have arisen some exaggerated notions as to the prevalence of drunkenness in Scotland. (British Medical fournal, 1880.) 